\title{
ON REGULATION OF CRYPTOCURRENCY: INTERNATIONAL EXPERIENCE ${ }^{1}$
}

\author{
Evgheni FLOREA \\ Doctor of Law, Associate Professor, \\ Comrat State University, Comrat, Republic of Moldova, \\ Head of Compliance Department, Quan2um OU cryptoexchange platform, Tallinn, Estonia \\ e-mail:florya@yahoo.com \\ https://orcid.org/0000-0001-7236-0695 \\ Elena S. PUSTELNIK \\ Master of Laws, Emory University School of Law, United States of America, \\ Paralegal, Privacy Compliance GDPR, Cybersecurity at Workplace \\ e-mail:espustelnik@gmail.com \\ https://orcid.org/0000-0002-0034-0879
}

The study is dedicated to various jurisdictions' approaches to cryptocurrency relations regulation. The digital assets'legal status in the European Union is analyzed both at the central level as well at the level of such EU members as Malta, Romania, Germany. Among the countries that geographically belong to Europe, but are not members of the European Union, Switzerland and the United Kingdom are considered in this aspect. The authors also reviewed the most important issues of cryptocurrency regulation in the largest economy in the world - the United States. The Asian region is represented in the study by the jurisdictions where digital assets are most widespread (China and Japan). The main conclusion is that the Republic of Moldova should develop the balanced approach to legalizing the new sphere of socio-economic relations by taking into consideration both positive and negative experience as well as the best legal practices of other states in this field.

Keywords: cryptocurrency, digital assets, blockchain, regulation, Bitcoin, EU Fifth AMLD Directive, cryptocurrency exchanges.

\section{DESPRE REGLEMENTAREA JURIDICĂ A CRIPTOMONEDEI: EXPERIENȚA INTERNAȚIONALĂ}

Prezentul studiu examinează abordările diferitor jurisdicții cu privire la reglementarea legală a relațiilor criptovalutare. Statutul juridic al activelor digitale în legislația Uniunii Europene este analizat atât la nivel central, cât și la nivelul unor state-membre UE precum Malta, România, Germania. Printre țările care aparțin geografic Europei, dar nu sunt membre ale Uniunii Europene, Elveția și Regatul Unit sunt analizate în acest aspect. Autorii, de asemenea, s-au axat pe problemele actuale ale reglementării criptomonedelor în cea mai mare economie din lume - Statele Unite ale Americii. Regiunea asiatică este reprezentată în studiu de țările în care activele digitale sunt cele mai răspândite (China și Japonia). Principala concluzie a autorilor este că pentru a dezvolta în Republica Moldova o abordare echilibrată a noii sfere de relații socio-economice criptovalutare este nevoie de a lua în considerențe experiența legislativă a altor state (atât pozitivăa, cât și negativă), precum și cele mai bune practici juridice de peste hotare.

Cuvinte-cheie: criptovalută, active digitale, blockchain, reglementări juridice, Bitcoin, a cincea directivă a UE, schimb criptovalutar.

\footnotetext{
${ }^{1}$ We would like to thank Antonia GORSHENIN for editing this article.
} 


\section{SUR LA RÉGLEMENTATION JURIDIQUE DE LA CRYPTOCURRENCE: EXPÉRIENCE INTERNATIONALE}

L'étude examine les approches de diverses juridictions en matière de réglementation juridique des relations de crypto-monnaie. Le statut juridique des actifs numériques dans la législation de l'Union européenne est analysé à la fois au niveau central et au niveau d'états membres de l'UE tels que Malte, la Roumanie et l'Allemagne. Parmi les pays qui appartiennent géographiquement à l'Europe, mais qui ne sont pas membres de l'Union européenne, la Suisse et le Royaume-Uni sont considérés sous cet aspect. Les auteur se sont également penché sur les questions d'actualité de la réglementation des crypto-monnaies dans la plus grande économie du monde - les États-Unis. La région asiatique est représentée dans l'étude par les états où les actifs numériques sont les plus répandus (Chine et Japon). La principale conclusion est que, du point de vue de l'expérience d'autres états (à la fois positive et négative), après avoir examiné les meilleures pratiques juridiques, il faut développer en République de Moldavie l'approche la plus équilibrée pour légaliser la nouvelle sphère de relations socio-économiques.

Mots-clés: crypto-monnaie, actifs numériques, blockchain, réglementation légale, Bitcoin, cinquième directive de l'UE, échanges de crypto-monnaie.

\section{О ПРАВОВОМ РЕГУЛИРОВАНИИ КРИПТОВАЛЮТ: МЕЖДУНАРОДНЫЙ ОПЫТ}

В данном исследовании рассматриваются подходы различных юрисдикиий к правовому регулированию криптовалютных отнотений. Анализируется правовой статус ицирровых активов в законодательстве Евросоюза как на центральном уровне, так и на уровне таких государств ЕС как Мальта, Румыния, Германия. Среди стран, которые географически относятся к Европе, но не являются членами Евросоюза, в данном аспекте рассматриваются Швейцария и Великобритания. Также авторы рассматривают актуальные проблемы регулирования криптовалют в крупнейшей экономике мира - США. Азиатский регион представлен в исследовании государствами, где цифровые активы получили наибольщее распространение (Китай и Япония). Главный вывод авторов состоит в том, чтобы с позищий имеющегося у других государств законодательного опыта (как позитивного, так и негативного), выработать в Республике Молдова максимально взвешенный подход клегализачии новой сферы социально-экономических отношений.

Ключевые слова: криптовалюта, иифровые активы, блокчейн, правовое регулирование, Биткоин, Пятая Директива ЕС, криптовалютная биржа.

\section{Introduction}

The new social relations arising from the emergence of digital assets have caused a need for the development of an appropriate legal regulatory mechanism. Different countries, depending on the degree of acceptance of the new technology and established legal traditions, have approached this issue differently.Our study is dedicated legal framework of cryptocurrency regulation in such jurisdictions as European Union, Malta, Estonia, Romania, Germany, The United Kingdom, Switzerland, The United States of America, People's Republic of China and Japan. Since the Republic of Moldova has not adopted yet any laws or regulations in this field, foreign legislative experience can provide a valuable experience for the future Moldovan law on cryptocurrency.

\section{European Union}

Cryptocurrency regulation in the European Unionare in their formative stages. The European Union authorities are quite wary of the new sphere. Indicative in this sense is the reaction to Libra, Facebook's digital currency, which the company intended to launch in the European Union. The alliance's finance ministers decided not to allow Libra or any other stablecoin to be used in the European Union. The ministers said in a joint statement that "no agreement to launch stablecoins will go into effect until 
regulatory, legal and regulatory risks have been identified and addressed" [1]. Meanwhile, work is already underway at the European Commission to develop specific rules to regulate crypto-assets and stablecoins [1].

Currently, theEuropean Court of Human Rightshas onlyone precedent related to cryptocurrency. In Skatteverket vs David Hedqvist [2]. Court ruled that:

1) Bitcoin is a currency, not a commodity,

2) Bitcoin exchange transactions for fiat currencies are exempt from VAT.

The Fifth Anti-Money Laundering Directive (5AMLD) has to be mentioned within EU regulatory framework [3]. This Directive is currently the main document of the European Union in the field of cryptocurrency regulation.

It should be noted that EU Directivesand Regulationshave different normative properties. Whereas the EU Regulation is a normative act of direct action, which does not require mediation by national law. The Directive, as a normative act, is indirect. This means that the competent authorities of the European Union have established a certain timeframefor the Member States to implement the Directive into national law, while the national authorities are free to choose the means and ways to achieve the goal [4, pp. 45-46]. As such, the Member States were required to implement the Directive norms byJanuary 10, 2020. The governing, supervisory and coordinating body for the Directiveimplementation is The European Banking Authority (EBA) [5].

In addition to the official definition of virtual currencies, the Fifth Directive also contains certain requirements for Member States to regulate this area:

- Empowering national financial monitoring units to obtain the addresses and identification of digital currenciesowners.

- cryptocurrency exchanges and wallets are required to register with the competent authorities at their location.
- the obligation of platforms providing cryptocurrency services to submit suspicious activity reports (SARs) and perform customer due diligence (CDD).

Countries in the European Union are implementing both, digital technologies and 5AMLD at varyious speeds. Among the jurisdictions, which are the most active in this area, Malta and Estonia are taking the lead.

\section{Malta}

The country is often referred to as a "blockchain island" for the activity that local authorities are doing in attracting investments in this area. Blockchain and cryptocurrencies are not merely legalized here. A holistic regulatory framework provides an extremely favorable climate for foreign investors to operate in the blockchain technology sector.

On July 4, 2018, the Parliament of Malta passed the following laws [6]:

- Digital Innovation Authority Act;

- Innovative Technology Arrangements and Services Act;

- The Virtual Financial Assets Act.

The last document is the most important for the industry. It covers the operations of traders, brokerages, exchanges and asset managers in Malta. The attractiveness of the "blockchain island" for cryptocurrency investments is eloquently demonstrated by the fact that Binance, the world's largest cryptocurrency exchange by volume, has moved its head office from Hong Kong to Malta [7].

Such rapid implementation of digital technology on the island has a downside. In January 2019, the International Monetary Fund (IMF) concluded that the growth of the blockchain sector in Malta "has created significant money laundering and terrorist financing risks in the island's economy" [8].

\section{Estonia}

According to the Doing Crypto Index, which included 23 countries where blockchain technology is most prominent, Estonia ranked first 
in terms of cryptocurrency friendliness [9]. And this should come as no surprise. The country that gave Skype to the world, actively supports the IT business, and in general strives to meet the needs and demands of the time in the field of digital technology. The former Soviet republic primarily attracts businesses from the former Soviet Union. Four main factors contribute to this:

- e-residency law, which allows foreign nationals to register a business in the country remotely and interact online with governmental agencies from anywhere in the world. No paperwork is required. All documents, including licenses, are issued solely electronically. The embodied concept of the "remote state" had the best effect on the investment climate. For a while after the law was passed, the weekly number of applications for online residency has exceeded the weekly birth rate in the country [10].

- country is the only non-offshore jurisdiction with zero percent income tax for entrepreneurs. A company doing business here only has to pay tax on undistributed profits, or profits that are distributed outside of Estonia. In other words, until the moment when a company decides to distribute profits outside Estonia, it is completely exempt from paying income tax.

- country's membership in the EU allows business projects registered here to legally carry out their economic activities throughout the European Union without physical presence in this territory.

- friendly attitude of the regulators, even if an investor speaks neither Estonian nor English. Even if you speak just Russian, you can always call and get a detailed answer to any question related to any aspect of doing business in the country.

These aspects do not mean that business activities are performed out here without proper control. Business representatives note, that at the moment, Estonian legislation regarding crypto-business is the strictest of the non-bind- ing, i.e. regulating the crypto-industry, rather than prohibiting it, in the world [10].

Estonia was the first in the EU to implement the provisions of 5AMLD. It did not adopt a separate normative act to regulate the crypto environment. The necessary norms were incorporated into the law "On Combating Money Laundering and Terrorist Financing" adopted on October 26, 2017 [11]. This document provided a legally regulated framework for businesses related to virtual currencies.

The new law has appointed theFinancial Intelligence Service as supervisory authority for virtual currency service providers which is a division of the Estonian Police and Border Guard Control (Article 69, part 3). In addition,voluminous Section 8 of the above law, called "Authorization and Prohibition to Provide Services"is dedicated to the requirements for conducting activities related to virtual currencies. The detailed rules of Section 8, provide clarity and allow all licensed individuals to legally trade, exchange, and invest in cryptocurrencies.

It should be noted that since July 1, 2020, the specialized legislation for crypto-businesses in the country has become noticeably stricter. These measures resulted from the scandal at the Estonian branch of the largest Danish commercial bank Danske Bank, which was involved in the laundering of $\$ 220$ billion [12]. This scandal was the largest of its kind in the history of the EU and strongly affected Estonia's reputation. It is obvious that the main culprit should be the Danish regulator that ignored six warning letters from the Estonian Financial Intelligence Service and did not take appropriate measures to stop the illegal activities [13].

To the credit of the Estonian authorities, their response was very swift and harsh, directly affecting the cryptocurrency business, which is associated with increased money laundering risks. In 2020, more than 1,000 cryptocurrency companies lost their licenses and fewer than 400 firms continue to operate [14]. 
The legislative changes boiled down to the following:

- all cryptocurrency businesses are equated with financial services in terms of anti-money laundering and counter-terrorist financing regulation;

- a firm offering services in the cryptocurrency sphere must be located and operated in Estonia;

- top managers and founders of cryptoprojects, who wish to obtain an Estonian license, must provide a complete set of documents, confirming the absence of the criminal record, relevant experience and the necessary education;

- company employees must be physically located in Estonia. Having a virtual office or rented premises for nominal address registration is no longer sufficient;

- a single virtual currency service provider license will replace the two previously existing licenses for providing virtual currency wallet services and for providing virtual currency exchange services;

- documents required to apply for a license must be submitted through a notary public or electronically through the Registry of Enterprises;

- state fee for the license increases from 345 to 3,300 Euros (10 times). The pending status of an application can be extended up to 120 days (previously the maximum period was 60 days);

- company must have a payment account in a credit institution, electronic money institution or payment institution on Estonian territory or another state of the European Economic Area;

- minimum authorized capital according to the new regulations is 12 thousand euros and must be paid in full;

- individuals who transfer cryptocurrencies in excess of 15 thousand euros per month and legal entities with monthly cryptocurrency transactions exceeding 25 thousand euros may at any time be required to provide documents proving the origin of funds;

- company applicant, while documents for the license are under review, must assure, through the Estonian Finance Department, that the application complies with the new legal norms [15].

\section{Romania}

The state is a part the European Union countries whose authorities have not shown any particular interest in cryptocurrencies and blockchain technology. This is eloquently demonstrated by the fact that the country is on the list of alliance members that have not fulfilled their obligations to implement 5AMLD into national legislation [16]. In this connection, the European'sCommission decision has demonstratedits position stating that "the Commission regrets that the respective member states failed to transpose the directive in a timely manner and calls on them to do so forthwith, given the importance of these rules for the collective interests of the EU... All member states should have implemented the rules of the 5th AntiMoney Laundering Directive by January 10, 2020... Legislative gaps arising in one Member State have an impact on the EU as a whole" [16]. In addition to Romania, the list of countries that did not meet the deadline also included Cyprus, Hungary, the Netherlands, Portugal, Slovakia, Slovenia and Spain [16].

Recognizing the fact that the implementation was late, the Romanian government urgently adopted a package of regulatory amendments through which the country's legislation was brought into compliance with 5AMLD. The amendments were made to Law No. 129/2019 on preventing and combating money laundering and terrorist financing, Law No. 15/2006 on credit institutions and capital adequacy, Code of Tax Procedure No. 207/2015 and several other acts [17].

The National Bank of Romania issued two press releases outlining its position regarding "virtual currencies" [18]. The first press 
release notes that "virtual currency" should be distinguished from national and foreign currency, as well as from electronic money. With reference to the report of the European Central Bank and the communication of the European Banking Authority, the Romanian regulator lists the risks associated with the use of "virtual currencies":

- lack of regulation and supervision;

- risks associated with money laundering and terrorist financing;

- risks of volatility;

- risks of inadequate security.

In the second press release, issued three years after the first one, the Romanian National Bank reiterated its position, describing "virtual coins" as "speculative, extremely volatile and risky assets". Therefore, credit institutions, in order to avoid reputational risks, are "not recommended" to take part in any transactions involving virtual currencies, including in terms of providing investment or trading services.

As a consequence, Romanian commercial banks rushed to close customer accounts of two local crypto platforms, CryptoCoin Pro and BTCxChange. The first platform, with more than 7,500 clients, was forced to change its jurisdiction to Luxembourg [19].

It should also be mentioned that in March 2018, the National Agency for Fiscal Administration (ANAF) stated that cryptocurrency transactions are taxable [20].

\section{Germany}

The Federal Republic of Germany ranks $33 \mathrm{rd}$ in the world in the adoption of cryptocurrencies [21] and ninth in the Global Innovation Index 2020 [22]. Nevertheless, the EU's largest economy is often looked back on by other members of the alliance, so the position of German authorities regarding cryptocurrencies seems particularly important.

The country was one of the first to define the legal status of digital assets. Back in 2011, the German regulator, the Federal Financial Supervisory Authority (BaFin), classified cryp- tocurrencies according to Art. 1 of the German Banking Act (Kreditwesengesetz) as financial instruments. They fall into a subcategory of socalled "units of account" (Rechnungseinheiten), which is a special category of financial instruments not based on the EU law [23].

In terms of taxation, German law is not as strict as the US tax law, where Bitcoin is recognized as property and is taxed on capital outflows. According to the regulation of the German Ministry of Finance, Bitcoin has been equated to means of payment, so the purchase of goods or payment for services with digital money is only subject to VAT [24].

Beginning in January 2020, German banks were allowed to store and conduct transactions with Bitcoin and other cryptocurrencies [25]. The new law stipulates that online banking services, which include transactions with stocks, bonds and cryptocurrencies, will only be available to German financial institutions that receive the appropriate license issued by BaFin. The demand for legal certainty in this area can be demonstrated by the fact that almost immediately after the adoption of this law, more than 40 banks expressed interest in obtaining a license for cryptocurrency services [26].

\section{The United Kingdom}

The country openly supports companies operating in the field of digital currencies, which often choose it because of the availability of all necessary infrastructure for comfortably conducting business, as well as a well-developed banking and financial sector. Nevertheless, the legal framework for cryptocurrency activity has not yet been developed. In terms of their legal nature, cryptocurrencies are considered (UK) "private money"in the United Kingdom $[27$, p. 2].

The issue of ICO also remains unregulated, although most of the tokens are subject to the existing legal framework of the country.It is important to note that Brexit has had little or no effect on the United Kingdom's position on 5AMLD. The country, albeit with a slight delay, 
still implemented the directive into national law by amending its 2019 Regulation [28].

The Financial Conduct Authority (FCA) and the Bank of England are responsible for the regulation of financial services in the UK. The FCA's functions include promoting effective competition in the interests of consumers, strengthening and protecting the integrity of the country's financial services sector, and protecting consumers from potential harm. On the other hand, the Bank of England works to reduce or eliminate risks that could pose a threat to the country's financial stability.

In the absence of a clear legal framework for the crypto business, British regulators have been very constructive. The FCA created a program called Innovation Hub [29]. Cryptocurrency companies participating in it can receive advice on the legal regulation of their current or future activities. In this regard, companies can test their business model for compliance with current UK legislation before launching their business. This is certainly a good initiative that allows potential investors to understand the possible legal risks associated with digital technologies without the threat of any repressive action from the regulator.

An important document that sheds light on a number of legal issues that may arise for cryptocurrency businesses is the Crypto Asset Guidelines published by the Office [30]. In the Guide, among other issues, the FCA outlines the limits of legal regulation depending on the type of crypto assets, which fall into three categories:

- Exchange tokens, which are not issued and maintained by any central authority and are intended to be used as a medium of exchange. They are usually a decentralized tool for buying and selling goods and services without traditional intermediaries such as central or commercial banks. Cryptocurrencies such as BTC, ETH, LTC, etc. should fall into this category. These crypto-assets are usually outside the "perimeter" of competence;
- Security tokens. They are tokens with specific characteristics granting rights and obligations akin to investments such as stocks or debt instruments, as stated in the Financial Services and Markets Act [31]. These tokens are inside the "perimeter" of regulation;

- Utility tokens provide the right to receive services or goods within a platform, but not of the same nature as investments. Under certain conditions, these tokens can fall under the category of electronic money, and thus be in the "perimeter" of regulation.

In general, the UK follows the path of industry regulation similar to traditional financial services.

\section{Switzerland}

As a global financial center, the country is reluctand to join the EU on its own initiative to avoid collective pressure on its banking system. Traditional finance is not Switzerland's only strength. According to the Global Innovation Index 2020, for the second year in a row, the country ranks first in the world in terms of innovation development, ahead of Sweden, the US and the UK [22].

Overall, this jurisdiction is not just blockchain-friendly, but is taking the lead in the global adoption of digital assets and distributed ledger technology. Large companies choose this country for their operations because of the stability and predictability of legal regulation, as well as of investors' rightsprotection. The development team of Etherium, the second most capitalized cryptocurrency, chose Switzerland to register its Ethereum Foundation platform [32]. Libra, a cryptocurrency-based payment system for Facebook users, is also registered here.

In January 2017, the city of Zug organized the independent government-backed Crypto Valley Association to promote blockchainrelated technologies [33].

The regulator for the crypto market is the Swiss Financial Market Supervisory Authority (FINMA), which reviews each ICO registra- 
tion case individually. FINMA has also issued Guidelines for companies interested in conducting ICO in the country, putting the main emphasis on anti-money laundering and securities regulation [34]. In a risk monitoring report, the Swiss regulator directly linked blockchain and cryptocurrencies to the increased money laundering risks through the country, which could threaten its reputation as a financial center. FINMA recognizes that new technologies have great potential to improve financial market efficiency. However, the higher speed, anonymity and global nature of such financial instruments make them attractive for illicit purposes [35]. Nevertheless, in August 2019, the agency first issued licenses to two cryptocurrency banks, SEBA Crypto and Sygnum, while also publishing fairly strict regulatory guidelines for blockchain payment services [36]. But not all companies meet the requirements. For example, the regulator ruled the $\$ 90$ million ICO from crypto-mining company Envion illegal, launching an investigation for financial market violations [37]. In connection with the case, FINMA said it would continue to take action against illegal ICOs that "violate or circumvent the supervisory law" [37].

In early 2020, the Swiss Ministry of Finance began discussing a regulation that would implement a legal framework to regulate blockchain and the crypto industry at the state level in August 2021 [38]. While the process has not yet been completed, most cryptocurrency activity is subject to general financial market regulations. Earlier, the Swiss government refused to create a separate legal framework to regulate blockchain and crypto industry. The authorities decided to amend just some laws that regulate different areas ranging from bankruptcy of companies to securities trading [39].

\section{The United States of America}

The country ranks first in the world by the number of CryptoATM, which indicates the high prevalence of digital assets among the population ${ }^{2}$. Overall, it is a very heterogeneous jurisdiction for cryptocurrency business. It is duly noted that the U.S. market is a dream and at the same time a nightmare of any cryptoproject [41]. This is due to the legal specifics of the largest global economy, where each state has its own legislation, and there are many committees, commissions, departments and agencies at the federal level, whose competence in terms of crypto industry is not yet been clearly enough defined.

The year 2013 turned out to be especially important for the cryptocurrency business in the country.

In November, the U.S. Senate (Committee on Homeland Security and Governmental Affairs) held a hearing on virtual currencies, calling them "digital cash". As a result of the hearing it was ruled not to ban the circulation of cryptocurrencies, but to work on the regulation of this sphere of activity [42].

Earlier in March of the same year, the U.S. Treasury Department's Financial Crimes Enforcement Network (FinCEN) announced that cryptocurrency to fiat money exchange operations should be regulated in the same way astraditional money exchange operations (for example, dollars to euros or vice versa). Companies providing such exchange services must register as financial service providers (Money Service Business) and report suspicious transactions (Suspicious Transaction Report) [43].

The U.S. court system has set an important legal precedent regarding crypto assets. In August 2013, the U.S. Court for the Eastern District of Texas in SEC vs. Trendon T. Shavers and Bitcoin Savings and Trust, issued a decision that effectively equated the first cryptocurrency with money. The plaintiff alleged that the defendant committed fraud by fraudulently misap-

\footnotetext{
${ }^{2}$ A crypto machine is similar to an ATM, a machine for transferring cash into cryptocurrency. According to CoinATMRadar, as of January 2021, there were 1,125 cryptoATMs installed in the U.S., more than ten times the number in second place Canada $(1,144)$ [40].
} 
propriating 263,104 in Bitcoin. According to the defendant, Bitcoin is not money, so the charge has no legal basis. In the ruling on the case, Judge Amos L. Mazzant specifically stated, “. Bitcoin can be used as money. It can be used to buy goods or services and to pay for individual living expenses. The only limitation of Bitcoin is that it is limited to those places that accept it as currency. However, it can also be exchanged for conventional currencies such as the U.S. dollar, euro, yen and yuan. Thus, Bitcoin is a currency or form of money..." [44].

The toughest stance on cryptocurrencies has been taken by the government's Securities and Exchange Commission (SEC). This primarily applies to ICOs - initial coin offerings to attract investors to fund a project. Considering cryptocurrency as securities, the agency has not yet proposed clear and understandable rules of the game for the crypto-business, which creates legal uncertainty in the market and significantly complicates the work of companies operating in this area. A number of actions of the American regulator prompted the crypto-business to be very cautious about the choice of the USA as a potential jurisdiction for ICO. In particular, the SEC banned Pavel Durov's TON cryptocurrency platform GRAM two weeks before its official launch [45]. On the same grounds, the agency sued Ripple, whose currency XRP makes top 10 by market capitalization [46]. Earlier, SEC fined another major player in the crypto industry, Block.one, developer of the EOSIO blockchain and EOS cryptocurrency, due to having unregistered ICOs, for \$24 million [47].

Clarity in the regulation of crypto-business may be increased by a bill sent to Congress, informally called the "Cryptocurrency Act." This document identifies three types of cryptocurrencies, each of which will have its own financial regulator:

- commodity, regulated by the Commodity Futures Trading Commission (CTFC);

- crypto-currency, regulated by Financial
Crimes Enforcement Network (FinCEN);

- crypto-security, regulated by the Securities and Exchange Commission (SEC) [48].

The crypto-community also has certain hopes with the new U.S. President Joe Biden, whose team includes specialists with a deep knowledge of blockchain technology and capable of pursuing a more friendly policy towards the crypto-industry. In part, these hopes are already beginning to be realized. In particular, the new President has decided to freeze the implementation of some of his predecessor Donald Trump's decrees [49]. This also affected the proposal to collect personal information about the contracting parties and transactions of cryptocurrency firms' clients, which were supposed to be carried out by FinCEN. Many crypto-business representatives took this initiative of the previous President extremely negatively, considering it "ruinous" for the field of digital currencies [50].

\section{China}

The Asian cryptocurrency market is the largest in the world. According to cryptoanalythical firm Chainalysis, $31 \%$ of all cryptocurrency transactions in 2020 (which is $\$ 107$ billion) were conducted in East Asia, $77 \%$ more than in the second largest region (Western and Northern Europe) [51]. China alone is home to $65 \%$ of the world's Bitcoin mining capacity [52].

Until 2017, the country could be considered a world leader in cryptocurrency transactions. The largest exchanges of digital assets with a multimillion-dollar daily turnover were operating here. The world's second economy accounted for up to $90 \%$ of all Bitcoin trading for some period of time [53].

China's dominance in this market did not last long, however, a series of governmental decisions were made that severely impacted the crypto industry in the country.

Originally six central governmental regulators - the People's Bank of China (PBOC), 
China Cyber Administration, Ministry of Industry and Information Technology, State Administration of Industry and Commerce, Banking Regulatory Commission and Securities Regulatory Commission - issued a joint Announcement on Prevention of Financial Risks Associated with Initial Token Offerings [54]. According to the document, virtual coin offerings were deemed unlicensed investment solicitation. Thus, the Chinese government effectively banned ICOs in the country.

Further, in the same month, the Financial Risk Control Committee of the PBOC obliged all cryptocurrency exchanges registered in Beijing to completely stop trading and registering new users [55]. Thus, the activities of cryptocurrency exchanges in China were forcibly suspended. Companies providing cryptocurrency exchange services were forced to change their jurisdiction to other, more loyal markets.

According to RosBiznesConsulting (RBC Group), as a result of the measures taken, in less than a month Bitcoin trading in yuans has fallen in the country to less than $1 \%$ of global turnover, and the daily trading volume has dropped from a peak of nearly 120,000 Bitcoins to less than one hundred [53].

In January 2018, Chinese government banned over-the-counter cryptocurrency markets as well asbuying and selling of crypto assets by individuals [56]. In February, authorities blocked internet access within the country to foreign crypto exchanges and ICO sites [56].

In fact, cryptocurrency trading is now banned in the country, but storage of digital assets is still allowed. At the same time, Chinese government, while limiting the circulation of cryptocurrencies as much as possible, is taking an active interest in the blockchain technology itself. National cryptocurrency, digital yuan, [57] which will have a physical and virtual form, is being tested in major cities across the country. It will be issued by the PBOC.

On January 1, 2020, the country's Cryptography Law came into force [58]. It does not talk directly about cryptocurrencies, but creates a regulatory framework for cryptography and password management standards. According to the document, the Central Cryptographic Agency is in charge of public cryptographic work and the development of regulatory principles for the industry.

In fact, the law is another step for China to create its own centralized digital currency. At the same time, there is almost no legal basis for the existence of other cryptocurrencies.

\section{Japan}

Support for innovative technology has always been a strength of the Japanese economy. Such transnational corporations as Sony, Panasonic, Toshiba, Hitachi are known worldwide. Therefore, it makes sense that blockchain technology and cryptocurrencies, which are unthinkable without mobile devices, found fertile ground in this country.

The impetus for the development of regulatory rules for crypto-business was the hacking of Tokyo-based crypto exchange Mt.Gox. By 2013 , the site was processing more than $70 \%$ of all Bitcoin transactions worldwide. The hack resulted in the loss of 744,408 BTC belonging to the exchange's customers, as well as about 100,000 of the exchange's own coins, totaling $\$ 480$ million (at 2014 exchange rates) [59]. Country's authorities could not ignore this case and began to develop their own cryptocurrency regulation. The process dragged on for more than three years and the law on virtual currency regulation was adopted only on April 1, 2017. [60] According to the document, cryptocurrency, including Bitcoin, receives the status of a means of payment in the country and performs a function of currency. At the same time, the law specifies that only Japanese yen is the official monetary unit in the country. Cryptocurrency regulation is assigned to the Financial Services Agency (FSA) of Japan, which is authorized to register cryptocurrency exchanges and monitor their activities. 
The aftermath of the Mt.Gox collapse led to the establishment of a number of fairly stringent requirements. For example, companies will have to be externally audited by the Internal Revenue Service, report regularly to the Government, and have at least $\$ 100,000$ in reserve funds.

The process of obtaining a license will require even more significant financial resources. Companies will have to pay a one-time fee of $\$ 300,000$. If the review results in a decision to deny a license, the money will not be refunded [59].

In January 2018, the largest virtual asset theft in the modern history occurred. Japanese crypto-exchange suffered again, this time it was Coincheck. As a result of a hacker attack, \$548 million was illegally withdrawn from its accounts [61]. This case demonstrated the serious vulnerability of "hot wallets" where cryptocurrency exchange money is stored.

The FSA reacted promptly-the hacked exchange was ordered to review its security system and conduct an internal investigation of the incident, which affected 260,000 people. The regulator also conducted a holistic inspection of all cryptocurrency exchanges in the country. The main goal of the authorities was to make sure that the financial conditions of these companies would allow them to fulfill their obligations to customers [62].

The main result of the events that took place was the Japanese government's approval of the creation of a self-regulatory mechanism for the cryptocurrency industry. On October 24, 2018, Japanese Virtual Currency Exchange Association (JVCEA) was organizedand officially recognized by the government regulator [63]. The organization consists of representatives of all crypto-exchanges in the country and has the authority to develop the necessary requirements for operators of crypto-asset exchange services, as well as to apply appropriate sanctions in case they violate the current legislation. The Financial Services Agency of Japan rightly decided that "it is better for experts to set the rules in a timely manner than for bureaucrats to do so" [64].

Another package of measures aimed at regulating the cryptocurrency industry was passed on May 1, 2020. It includes amendments to the Act on Settlement of Funds (ASF) and the Financial Instruments and Exchanges Act (FIEA) [65]. The main purpose of the amendments is to increase regulatory certainty and further protect consumers. The innovations provide for stricter control over derivatives and in-depth development of risk management model related to hacking of crypto-exchanges. In particular, all cryptocurrency firms are now required to separate user deposits from their own funds by engaging third-party cold wallet services. For hot wallet services, the requirements consist of the need to store funds in the same amount as users', so that in the case of a hacker attack, they can recover the stolen funds [65].

In addition, the amendments use the new, more precise legal term "cryptocurrency assets" instead of the former "virtual currency" [65].

\section{Conclusions}

As we can see, the legal regulation of digital assets varies greatly around the world. Approaches range from progressive (Japan, Switzerland, Germany, Malta, Estonia) to restrictive (China). The intermediate position is occupied by jurisdictions with little interest in new technologies (Romania, Hungary, Spain, Cyprus, the Netherlands, Portugal, Slovakia, Slovenia). Due to the specific traditions of legal regulation in the United States and the United Kingdom, these countries cannot be included in any of the above groups, although de facto digital financial legal relations are allowed in both of them, and de jure are at the stage of their formation. It seems that the objective of the Moldovan authorities in this sense is to develop the most balanced approach to the legalization of the new sphere of social and economic relations from the perspective 
of the experience of other countries (both positive and negative), having considered the best legal practices.

\section{Bibliography}

1. EU agrees tough line on digital currencies like Facebook's Libra // Reuters - 05.12.2019. [Electronic resource]. URL: https://www.reuters.com/ article/us-eu-ecofin-cryptocurrencies/eu-agreestough-line-on-digital-currencies-like-facebookslibra-idUSKBN1Y91E4(access date: 13.01.2021).

2. Skatteverket $v$ David Hedqvist. Judgment of the Court (Fifth Chamber) of 22 October 2015. Case C-264/14//EUR-Lex. Access to European Union law. [Electronic resource]. URL: https://eur-lex.europa.eu/legal-content/EN/ TXT/?uri=CELEX\%3A62014CJ0264 (date of reference: 13.01 .2021$)$.

3. DIRECTIVE (EU) 2018/1673 OF THE EUROPEAN PARLIAMENT AND OF THE COUNCIL of 23 October 2018 on combating money laundering by criminal law//Official Journal of the European Union. 12.11.2018. L 284. P.2230. [Electronic resource]. URL: https://eur-lex. europa.eu/eli/dir/2018/1673/oj(date of reference: 13.01.2021).

4. ШИРИНСКИЙ, О. Ю. Европейское право: учеб. пособие. - Минск: РИВШ, 2015.

5. COMMUNICATION FROM THE COMMISSION on an Action Plan for a comprehensive Union policy on preventing money laundering and terrorist financing. European Commission. Brussels, 7.5.2020 [Electronic resource]. URL: https:// ec.europa.eu/finance/docs/law/200507-anti-moneylaundering-terrorism-financing-action-plan_en.pdf (Access date: 13.01.2021).

6. The establishment of the Malta Digital Innovation Authority; the Framework for the Certification of Distributed Ledger Technology Platforms and Related Service Providers; and a Virtual Currency Act. Parliamentary Secretariat for Financial Services, Digital Economy and Innovation. Office of the Prime Minister. [Electronic resource]. URL: https://meae.gov.mt/en/Public_Consultations/OPM/ Documents/PS\%20FSDEI\%20-\%20DLT\%20Regulation\%20Document\%20OUTPUT.PDF(access date: 14.01.2021).

7. Binance moved to Malta // Rambler Finance - 26.03.2018. [Electronic resource].URL: https:// finance.rambler.ru/markets/39455696-binance-pereehal-na-maltu/(date of reference: 14.01.2021).
8. Blockchain carries 'significant risks' // Times of Malta - 24.01.2019. [Electronic resource]. URL: https://timesofmalta.com/articles/view/blockchaincarries-significant-risks.699960(access date: 14.01.2021).

9. Названы лучшие страны для криптобизнеса// Корреспондент.net- 29.03.2019. [Electronic resource]. URL: https://korrespondent.net/business/ financial/4080744-nazvany-luchshye-strany-dliakryptobyznesa (date of reference: 15.01.2021).

10. Как Эстония, приравняв обмен и хранение криптовалют к обычным деньгам, сделала их легальным средством платежа// Moneypipe 12.10.2020. [Electronic resource]. URL: https:// habr.com/ru/company/moneypipe/blog/521294/ (access date: 15.01.2021).

11. Money Laundering and Terrorist Financing Prevention Act. Passed 26.10.2017. Entry into force

27. 11.2017 // Riigi Teataja. [Electronic resource]. URL: https://www.riigiteataja.ee/en/eli/ ee/509012020001/consolide/current\#(access date: 15.01.2021).

12. For more details on the Danske Bank scandal seеЕПИФАНОВАМ. Сумма, вдевятьраз, превышающаяВВПЭстонии// Новаягазета 19.09.2018. [Electronic resource]. URL: https:// novayagazeta.ru/articles/2018/09/19/77887-glavadanske-bank-podal-v-otstavku-iz-za-skandala-s-otmyvaniem-deneg(date of reference: 15.01.2021).

13. Как один банкир вскрыл аферу в Danske Bank на \$234 млрд// Ведомости - 24.10.2018. [Electronic resource]. URL:https://www.vedomosti.ru/finance/articles/2018/10/24/784536-kakodin-bankir-vskril-aferu-v-danske-bank-na-234milliarda(date of reference: 16.01.2021).

14. В Эстонии лишены лицензий более тысячи фирм сектора криптовалют// Postimees 13.12.2020. [Electronic resource]. URL: https://rus. postimees.ee/7132115/v-estonii-lisheny-licenziybolee-tysyachi-firm-sektora-kriptovalyut(access date: 16.01.2021).

15. Эстония изменила правила регистрации биткоин-компаний: что нужно знать// ForkLog08.07.2020. [Electronic resource]. URL: https:// forklog.com/estoniya-izmenila-pravila- registratsiibitkoin-kompanij-chto-nuzhno-znat/(access date: 15.01.2021).

16. Anti-Money Laundering: Commission urges 8 MEMBER STATES and the UK to fully transpose the 5th Anti-Money Laundering Directive. May 2020 infringements package: key decisions 
// EUBusiness - 14.05.2020 [Electronic resource]. URL:https://www.eubusiness.com/topics/eulaw/ infringements-may.20(access date: 16.01.2021).

17. Ordonanță de urgență nr. 111 din 1 July 2020. Guvernul României. Monitorul Oficial. №. 620. 15.07.2020.

18. Comunicat referitor la schemele de monedă virtuală // Banca Națională a României - 11.03.2015. [Electronic resource]. URL: https://www.bnr.ro/ page.aspx?prid=10016 (access date: 16.01.2021); Poziția Băncii Naționale a României în legătură cu monedele virtuale - 06.02.2018. [Electronic resource]. URL: https://www.bnr.ro/page. aspx?prid=14338(date of reference: 16.01.2021).

19. Băncile facă măcel în piaţa de criptomonede din România după comunicatul BNR. CryptoCoinPRO este a doua platformă de tranzacţionare care nu mai poate opera conturi în băncile româneşti // Ziarul Financiar - 16.02.2018. [Electronic resource]. URL: https://www.zf.ro/banci- si-asigurari/bancilefac-macel-in-piata-de-criptomonede-din-romaniadupa-comunicatul-bnr-cryptocoin-pro-este-a-douaplatforma-de-tranzactionare-care-nu-mai-poateopera-conturi-in-bancile-romanesti-17001476(date of reference: 16.01.2021).

20. Românii cu Bitcoin, datori la Fisc. Trebuie plătit impozit pe venit și contribuții sociale, deși monedele virtuale nu sunt reglementate în România // LIBERTATEA - 04.03.2018. [Electronicresource]. URL: https://www.libertatea.ro/stiri/ exclusiv-romanii-cu-bitcoin-datori-la-fisc-trebuieplatit-impozit-pe-venit-si-contributii-sociale-desimonedele-virtuale-nu-sunt-reglementate-in-romania-2163395(date of reference: 17.01.2021).

21. The 2020 Global Crypto Adoption Index // Chainalysis. [Electronic resource]. URL:https:// go.chainalysis.com/rs/503-FAP-074/images/ Index $\% 201$ ist $\% 20$ of $\% 20$ countries.pdf(access date: 21.01.2021).

22. The Global Innovation Index 2020: Who Will Finance Innovation? Cornell University, INSEAD, and WIPO (2020). Ithaca, Fontainebleau, and Geneva/Global Innovation Index. [Electronic resource]. URL: https://www.globalinnovationindex.org/Home(access date: 18.01.2021).

23. ASTAPOVA. Правовое регулирование криптовалюты в Германии в 2020 году// InternationalWealth-13.08.2020. [Electronic resource]. URL: https://internationalwealth.info/cryptocurrency/pravovoye-regulirovaniye-kriptovalyutyv-germanii-v-2020-godu/(date of reference: 21.01.2021).
24. В Германии ВТС приравняли к платежным средствам с точки зрения налогов// RosBusinessConsulting-01.03.2018. [Electronic resource]. URL:https://www.rbc.ru/crypto/news /5a97c0e69a79474a03e38a11(date of reference: 21.01.2021).

25. HOLTERMANN F. Neues Geldwäschegesetz - Banken dürfen Bitcoin verwahren//Handelsblatt - 27.11.2019. [Electronic resource]. URL: https://www.handelsblatt.com/finanzen/ maerkte/devisen-rohstoffe/kryptowaehrungenneues-geldwaeschegesetz-banken-duerfen-bitcoinverwahren/25276392.html?ticket=ST-8338439 -BoxxGZSi6YCjNmbrYO1j-ap1(access date: 21.01.2021).

26. DROST F.M., HOLTERMANN F. Banken wollen ins Krypto-Geschäft einsteigen // Handelsblatt - 07.02.2020. [Electronic resource]. URL: https://www.handelsblatt.com/finanzen/ banken-versicherungen/digitale-assets-bankenwollen-ins-krypto-geschaeft-einsteigen/25521910. html?ticket=ST-3407008-vwNttvVLFisRjfjjSLGYap2(date of reference: 21.01.2021).

27. Обзор законодательного регулирования криптовалют в отдельных государствах. ОбзорKPMG. Ноябрь 2017. [Electronic resource]. URL: http://ecommercelaw.ru/sites/default/files/ ru-ru-cryptocurrency-legislative-regulationworldwide-november-2017-upd.pdf(access date: 20.01.2021).

28. The Money Laundering and Terrorist Financing (Amendment) Regulations 2019. No. 1511. 19.12.2019 // legislation.gov.uk [Electronic resource]. URL: https://www.legislation.gov.uk/ uksi/2019/1511/introduction/made(access date: 20.01.2021).

29. Cryptoassets Taskforce: final report. HM Treasury, Financial Conduct Authority, Bank of England. October 2018. Crown copyright 2018 // gov.uk - 29.10.2018. [Electronic resource]. URL: https://www.gov.uk/government/publications/ cryptoassets-taskforce(access date: 20.01.2021).

30. Guidance on Cryptoassets Feedback and Final Guidance to CP 19/3. Financial Conduct Authority. July 2019. [Electronic resource]. URL: https://www.fca.org.uk/publication/policy/ps19-22. pdf(accessed 20.01.2021).

31. The Financial Services and Markets Act 2000 (Regulated Activities) Order 2001. No. 544. 26.02.2001// legislation.gov.uk [Electronic resource]. URL: https://www.legislation.gov.uk/ uksi/2001/544/introduction/made(date of access: 20.01.2021). 
32. Ethereum Foundation [Electronic resource]. URL: https://bytwork.com/companies/ethereumfoundation(access date: 18.01.2021).

33. Crypto Valley [Electronic resource]. URL: https://cryptovalley.swiss/ (access date: 19.01.2021).

34. FINMA publishes ICO guidelines // Swiss Financial Market Supervisory Authority - 16.02.2018. - [Electronic resource]. URL: https://www.finma.ch/ en/news/2018/02/20180216-mm-ico-wegleitung/ (access date: 19.01.2021).

35. New FINMA report: Risk Monitor // Swiss Financial Market Supervisory Authority 10.12.2019. [Electronic resource]. URL: https:// www.finma.ch/en/news/2019/12/20191210-mmrisikomonitor/(access date: 19.01.2021).

36. Швейцарский регулятор впервые выдал банковские лицензии блокчейн-компаниям// ForkLog - 26.08.2019. [Electronic resource]. URL: https://forklog.com/shvejtsarskij-regulyatorvpervye-vydal-bankovskie-litsenzii-blokchejnkompaniyam/(access date: 19.01.2021).

37. FINMA ascertains illegal activity by envion AG // Swiss Financial Market Supervisory Authority - 27.03.2019. [Electronic resource]. URL: https://www.finma.ch/en/news/2019/03/20190327--mm---envion/(access date: 19.01.2021).

38. Consultation initiated on blanket ordinance in area of blockchain // Federal Department of Finance. Swiss Confederation - 19.10.2020. [Electronic resource]. URL: https://www.admin.ch/gov/ en/start/documentation/media-releases.msg-id80775.html(date of access: 18.01.2021).

39. Swiss Finance Minister Rejects Specific Blockchain Legislation in Favor of Current Laws // Cointelegraph - 04.12.2018. [Electronic resource]. URL: https://cointelegraph.com/news/ swiss-finance-minister-rejects-specific-blockchainlegislation-in-favor-of-current-laws(access date: 18.01.2021).

40. Bitcoin ATMs by Country // Coin ATM Radar - 24.01.2021. [Electronic resource]. URL: https://coinatmradar.com/countries/(access date: 24.01.2021).

41. США как юрисдикция для криптовалют, ICO и блокчейн-стартапов// ForkLog - 21.04.2018. [Electronic resource]. URL: https://forklog.com/ ssha-kak-yurisdiktsiya-dlya-kriptovalyut-ico-iblokchejn-startapov/(accessed 20.01.2021).

42. Beyond Silk Road: Potential Risks, Threats, and Promises of Virtual Currencies // US Senate Committee on Homeland Security and Governmen- tal Affairs - 18.11.2013. [Electronic resource]. URL: https://www.hsgac.senate.gov/hearings/beyondsilk-road-potential-risks-threats-and-promises-ofvirtual-currencies(access date: 21.01.2021).

43. Application of FinCEN's Regulations to Persons Administering, Exchanging, or Using Virtual Currencies // Financial Crimes Enforcement Network. An official website of the United States Government. 18.03.2013. [Electronic resource]. URL: https://www.fincen.gov/resources/ statutes-regulations/guidance/application-fincensregulations-persons-administering(access date: 23.01.2021).

44. SECURITIES and EXCHANGE COMMISSION vs. TRENDON T. SHAVERS and BITCOIN SAVINGS AND TRUST. CASE NO. 4:13-CV-416. Memorandum Opinion regarding the court's subject matter jurisdiction. United States District Court EASTERN DISTRICT OF TEXAS SHERMAN DIVISION. 06.08.2013. [Electronic resource]. URL:https://ia800708.us.archive.org/31/ items/gov.uscourts.txed.146063/gov.uscourts. txed.146063.23.0.pdf(accessed 23.01.2021).

45. SEC Halts Alleged \$1.7 Billion Unregistered Digital Token Offering // US Securities and Exchange Commission. Press Release - 11.10.2019. [Electronic resource]. URL: https://www.sec.gov/news/press-release/2019212 ? fbclid=Iw A R 0n Xy G 1 tVkM1 IQJ 8 vpQmvpQEpe2PchObZUO2cT5AaGP4-d8GuNqtyQ1Q(accessed 23.01.2021).

46. SEC подала иск против Ripple// ForkLog - 12/23/2020. [Electronic resource]. URL: https:// forklog.com/sec-podala-isk-protiv-ripple/(access date: 23.01 .2021 ).

47. SEC Orders Blockchain Company to Pay \$24 Million Penalty for Unregistered ICO // US Securities and Exchange Commission. Press Release - 30.09.2019. [Electronic resource]. URL: https://www.sec.gov/news/press-release/2019-202(accessed 23.01.2021).

48. «Закон о криптовалюте 2020 года»: В Конгресс США внесли новый законопроект о регулировании криптоиндустрии// CoinSpot 20.12.2019. [Electronic resource]. URL: https:// coinspot.io/law/us_and_canada/zakon-o-kriptovalyute-2020-goda-v-kongress-ssha-vnesli-novyj-zakonoproekt-o-regulirovanii-kriptoindustrii/(access date: 23.01.2021).

49. Regulatory Freeze Pending Review. Memorandum for the heads of executive departments and agencies // The White House - 20.01.2021. [Elec- 
tronic resource]. URL: https://www.whitehouse. gov/briefing-room/presidential-actions/2021/01/20/ regulatory-freeze-pending-review/(date of access: 23.01.2021).

50. ДжекДорси, a16zu Coinbasepaскритиковали нормы регулирования индустрии от FinCEN// ForkLog - 06.01.2021. [Electronic resource]. URL: https://forklog.com/dzhek-dorsi-a16z-i-coinbaseraskritikovali-normy-regulirovaniya-kriptoindustrii-ot-fincen/(accessed 23.01.2021).

51. The 2020 Geography of Cryptocurrency Report. Analysis of Geographic Trends in Cryptocurrency, Adoption, Usage and Regulation. September 2020. - P. 37. [Electronic resource]. URL: https:// go.chainalysis.com/2020-geography-of-cryptoreport.html(access date: 24.01.2021).

52. Bitcoin Mining Map//Cambridge Centre for Alternative Finance - 24.01.2021. [Electronic resource]. URL: https://cbeci.org/mining_map(access date: 24.01.2021).

53. Что на самом деле происходит в Китае. Запрет криптовалют и бум блокчейна// RosBusinessConsulting - 31.07.2018. [Electronic resource]. URL: https://www.rbc.ru/crypto/news/5b6028d99a 79471 eaa4ac212(date of reference: 24.01.2021).

54. Announcement by the People's Bank of China, China Cyber Administration, Ministry of Industry and Information Technology, Ministry of Industry and Commerce, Banking Regulatory Commission, Securities Regulatory Commission and Insurance Regulatory Commission on preventing the risks of token issue financing // People's Bank of China - 04.09.2017. [Electronic resource]. URL:http://www.pbc.gov.cn/goutongji aoliu/113456/113469/3374222/index.html(access date: 24.01.2021).

55. Китай закрывает все криптовалютные биржи//Экономическая правда - 15.09.2017. [Electronic resource]. URL: https://www.epravda. com.ua/rus/news/2017/09/15/629162/(date of reference: 24.01.2021).

56. A Quick Guide to Crypto Regulators and Companies in China // Global Coin Research 19.08.2020. [Electronic resource]. URL: https:// globalcoinresearch.com/2020/08/19/a-quick-guideto-crypto-regulators-and-companies-in-china/(access date: 24.01.2021).
57. Major Chinese cities plan large-scale tests of digital currency in 2021 // Global Times 24.01.2021. [Electronic resource]. URL: https:// www.globaltimes.cn/page/202101/1213705.shtml (access date: 24.01.2021).

58. China's Congress Passes Cryptography Law, Effective Jan. 1, 2020 // Coindesk - 26.10.2019. [Electronic resource]. URL: https://www.coindesk. com/chinas-congress-passes-cryptography-laweffective-jan-1-2020(access date: 24.01.2021).

59. АСМАКОВ А. Бесконечная история: обрушат ли цену биткоина выплаты инвесторам Mt. Gox?// Forklog - 24.09.2018. [Electronic resource]. URL: https://forklog.com/beskonechnaya-istoriya-obrushat-li-tsenu-bitkoina-vyplatyinvestoram-mt-gox/(accessed 24.01.2021).

60. В Японии вступил в силу признающий биткоины платежным средством закон// RosBusinessConsulting - 01.04.2017. [Electronic resource]. URL: https://www.rbc.ru/rbcfreenews/58df61919a7 9476eb3bacbf4(date of reference: 24.01.2021).

61. Кража криптовалюты в Японии на $\$ 548$ млн была вызвана вирусом// TASS - 08.03.2018. [Electronic resource]. URL: https://tass.ru/ ekonomika/5017282(access date: 25.01.2021).

62. Japan raps Coincheck, orders broader checks after $\$ 530$ million cryptocurrency theft // Reuters - 29.01.2018. [Electronic resource]. URL: https://www.reuters.com/article/us-japan-cryptocurrency/japan-raps-coincheck-orders-broaderchecks-after-530-million-cryptocurrency-theftidUSKBN1FI06S(access date: 25.01.2021).

63. Japanese Virtual Currency Exchange Association JVCEA. [Electronic resource]. URL: https:// jvcea.or.jp/about/(access date: 25.01.2021).

64. Кража криптовалюты в Японии на $\$ 548$ млн была вызвана вирусом// CoinSpot 24.10.2018. [Electronic resource]. URL: https:// coinspot.io/law/asia-and-africa/yaponiya-razreshila-kriptovalyutnoj-industrii-samoregulirovanie/ (access date: 25.01.2021).

65. Япония приняла новое законодательство в области регулирования криптовалют// ForkLog - 01.06.2019. [Electronic resource]. URL: https:// forklog.com/yaponiya-prinyala-novoe-zakonodatelstvo-v-oblasti-regulirovaniya-kriptovalyut/ (access date: 26.01.2021). 